\title{
University vs. Research Institute? The Dual Pillars of German Science Production, 1950-2010
}

\author{
Jennifer Dusdal $^{1}$ D $\cdot$ Justin J. W. Powell $^{1}\left(\mathbb{D} \cdot\right.$ David P. Baker $^{2} \mathbb{D} \cdot$ \\ Yuan Chih $\mathrm{Fu}^{3}$ (D) Yahya Shamekhi ${ }^{2} \cdot$ Manfred Stock $^{4}$
}

Published online: 7 February 2020

(C) The Author(s) 2020

\begin{abstract}
The world's third largest producer of scientific research, Germany, is the origin of the research university and the independent, extra-university research institute. Its dual-pillar research policy differentiates these organizational forms functionally: universities specialize in advanced research-based teaching; institutes specialize intensely on research. Over the past decades this policy affected each sector differently: while universities suffered a lingering "legitimation crisis," institutes enjoyed deepening "favored sponsorship"-financial and reputational advantages. Universities led the nation's reestablishment of scientific prominence among the highly competitive European and global science systems after WWII. But sectoral analysis of contributions to science, technology, engineering, mathematics, and medical and health journal publications (1950-2010) finds that Germany's small to medium-sized independent research institutes have made significant, growing contributions, particularly in publishing in higher impact journals proportionally more than their size. Simultaneously-despite dual-pillar policy implications-the university sector continues to be absolutely and relatively successful; not eclipsed by the institutes. Universities have consistently produced two-thirds of the nation's publications in the highest quality journals since at least 1980 and have increased publications at a logarithmic rate; higher than the international mean. Indeed, they
\end{abstract}

Jennifer Dusdal

jennifer.dusdal@uni.lu

1 Institute of Education and Society, University of Luxembourg, 11, Porte des Sciences, 4366 Esch-sur-Alzette, Luxembourg

2 Department of Education Policy Studies, The Pennsylvania State University, University Park, PA 16802, USA

3 Graduate Institute of Technical and Vocational Education, National Taipei University of Technology, 1, Sec. 3, Zhongxiao E. Rd., Taipei 10608, Taiwan, R.O.C.

4 Institute of Sociology, Martin Luther University of Halle-Wittenberg, Emil-Abderhalden-Str. 26-27, 06099 Halle/Saale, Germany 
led Germany into the global mega-science style of production. Contrary to assumed benefits of functional differentiation, our results indicate that relative to their size, each sector has produced approximately similar publication records. While institutes have succeeded, the larger university sector, despite much less funding growth, has remained fundamental to German science production. Considering these findings, we discuss the future utility of the dual-pillar policy.

Keywords Germany $\cdot$ University $\cdot$ Research institute $\cdot$ Research policy $\cdot$ Science production $\cdot$ STEM+

\section{Introduction: Germany-Innovator in the Center of Europe}

Germany, currently the world's third largest producer of scientific research, is credited with the origins of two major organizational forms responsible for generating scientific discovery worldwide: the research university and the independent, extra-university research institute (hereafter, institute). ${ }^{1}$ As is well known, over the late 18th and early 19th century, universities in German-speaking Europe innovatively integrated a set of principles around higher education and scientific research, most importantly the nexus of research and teaching, as the fundamental principle of the modern research university. Eventually, the new research-oriented university took shape and by the mid-19th century was internationally celebrated and emulated, though somewhat misinterpreted, including in nascent American universities (e.g. Geiger 2004 [1993]; Lenhardt 2005; Ash 2006). While innovations continue elsewhere, the core principles behind this original model of the research university are now evident in universities throughout the world, and by the end of the period examined here there were 142 research-active universities in Germany. After developing the research university, Germany also pioneered the independent, government-funded, and highly prestigious research institute, a salient model frequently employed throughout the country, financed to varying degrees by various levels of government. Fully autonomous from universities and private interests and with academic freedom from the state in scientific pursuits, by 2010 there were 427 institutes undertaking basic scientific research and publishing science, technology, engineering, and mathematics, plus medicine and health journal articles (hereafter, STEM+ papers), primarily coordinated within four umbrella organizations (Fraunhofer, Helmholtz, Leibniz, and Max Planck). With some modification, the form of the research institute has also been replicated outside Germany, such as the internal research laboratories within the U.S. National Institutes of Health, the researchers and laboratories of France's Centre National de la Recherche Scientifique (CNRS), and the national Academies of Science in the former USSR and China (Kreckel

\footnotetext{
1 "Institute" refers here only to stand-alone, independent organizations primarily undertaking scientific research with dedicated streams of state funding. The word "institute" has various meanings, however, and can also refer to research centers or clusters functioning within universities and other organizations, none of which are the kind examined here.
} 


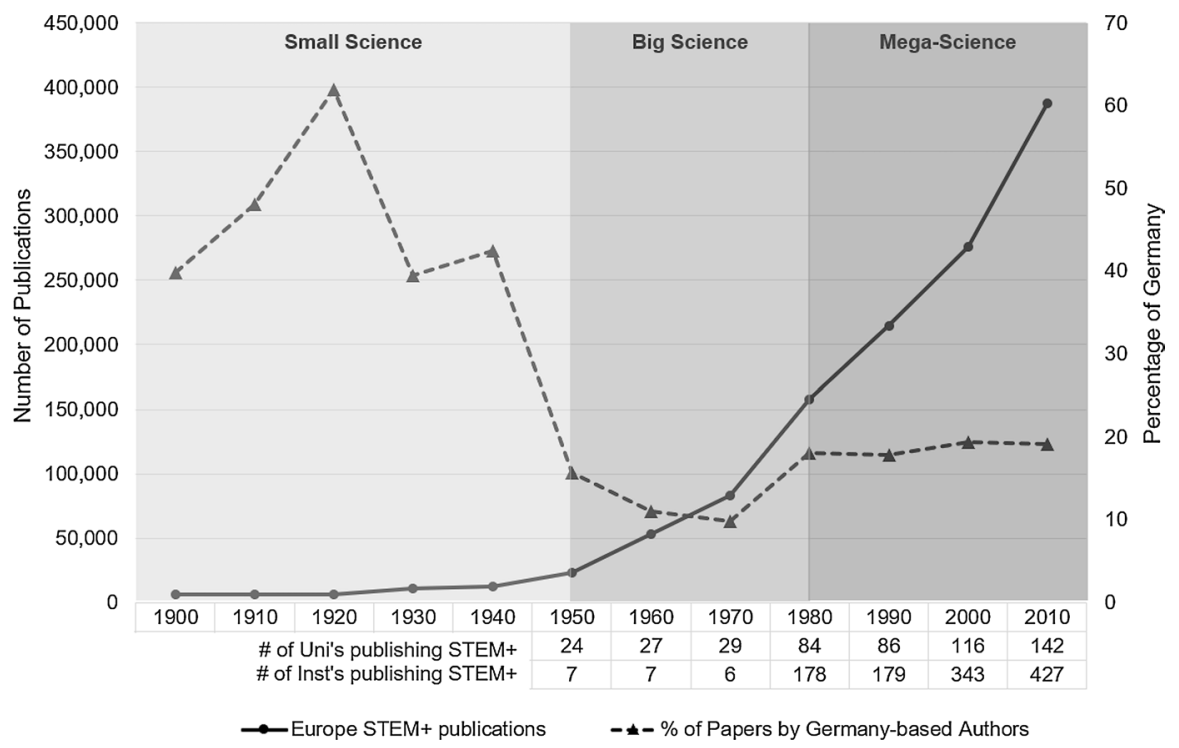

Fig. 1 Estimated Volume of STEM+ Journal Articles Authored by European Scientists; Percentage of Papers by Germany-based Authors; and Number of Universities and Research Institutes Contributing to Publications in Germany, 1900-2010. Source SPHERE project database of SCIE publications (Clarivate Analytics' Web of Science). Note Number of universities and institutes with at least one STEM+ publication approximates but does not necessarily match official totals of all universities and institutes as a small number may not have contributed articles in the database's journals in selected years

2008; Robin and Schubert 2013; Oleksiyenko 2014). Here, we primarily investigate these "dual pillars" of German science production (see also Powell and Dusdal 2017a).

Consequently, and even in the face of severe national, regional, and global crises, the country's science production has been significant over the 20th centurydominating early, fading during the middle, and rebounding in later decades. To put Germany's contribution in perspective, shown in Fig. 1 are estimated annual journal publications in STEM+ from the European region and the percentage of these from Germany (data source described below). This region has been a major producer across a "century of science" of unparalleled discovery, from approximately the late 19th century until the present (Powell et al. 2017a, b). Termed the "small science" phase of the 20th century, notable for its novel increase in scientific disciplines, topics, and discoveries, it was launched by European scientists who were then authoring about two-thirds of the world's scientific journal publications, many of whom worked within research universities inspired by the German model (de Solla Price 1963). And a large share of this production was from Germany itself. For example, of the estimated 6,300 STEM+ papers from European countries published in 1900, 70 percent were authored by at least one Germany-based scientist. Not surprisingly given the critical junctures due to an illiberal fascist regime, defeat in WWII, plus its post-WWII political division, Germany's proportion began a steep decline from about 1940, dropping to below 10 percent of Europe's papers 
by 1970 . This coincided with what has been referred to as the "big science" phase ${ }^{2}$ with its unprecedented growth in papers from scientists researching in a growing number of nations, most notably in the U.S. Even with a scientifically weakened Germany, Europe during this period continued to contribute just under 40 percent of global journal articles in STEM+. The worldwide culmination of the trends already occurring in the emerging research universities in Germany by 1900 may be termed "mega-science," which by the 1980s marked the intensification of scientific capacity-building and publication in Europe - and globally (Baker and Powell forthcoming). The publication rate, reflecting unexpected "pure exponential growth," rose to over one million annual papers by 2010 , authored by scientists working in dozens more countries, resulting in large part from global higher education expansion (Powell et al. 2017a, b). In the midst of this global sea-change, by the 1980s German science had rebounded and consistently contributed just under 20 percent of a constantly expanding volume of papers from Europe. By 2010, the country's rebuilt and growing science capacity produced over an estimated 74,000 new STEM+ papers, third globally after the U.S. and China.

Germany's current science production is clearly impressive. Yet unlike other leading productive countries, it relies on a higher education and research policy that increasingly diverges from the rising centrality of the research university in the majority of nations' science production. Supported by deeply held political and cultural assumptions, since 1950, the guiding principle behind the German Federal Republic's and then a reunified Germany's research policy is the image of universities and institutes each representing a supporting but differentiated "pillar" of science production. By the 20th century, Germany's states (Bundesländer) chartered, funded, and managed universities that had the specific function of university education, including preparation of the country's future scientists. Universities, relying on competitive $R \& D$ revenue, were undertaking research as part of their mission, but this role was assumed to be steadily and properly eclipsed by the institutes, the home of world-leading specialists in selected scientific fields. Extra-university research institutes were considered organizations of the "best and brightest" researchers guided by prestigious senior scientists in the systematic pursuit of the most cuttingedge science possible. Their overall conditions for research are characterized by well-resourced dedicated streams of federal and Bundesländer funding, albeit recently with some competitive revenue streams added in and becoming increasingly important. While the early charter of some institutes involved partnerships with industry (a form of doing research also pioneered in Germany, but not examined here), they were never limited to research primarily for economic, military, or state purposes, and have evolved into centers of fundamental scientific inquiry to be

\footnotetext{
2 The concept of "big science" in this paper is based on de Solla Price's (1986) analysis that science is now more than just the growth of the science system and an increase of scientific publications; rather, the organization of research involves larger teams engaged in collaborative work, with research tasks requiring more financial support and personnel and coordination, and scientific innovation increasingly intertwined with technological development (see Felt et al. 1995).
} 
shared openly with the world's scientific community in the standard fashion of journal articles, conferences, and so forth.

As the term "dual pillars" implies, while functionally different to a degree, the two main organizational forms of science are widely assumed essentially equal in their importance. Intentionally and unintentionally, this assumption has, however, neither led to equality in resource allocation nor in legitimation. Instead, the dualpillar model has yielded uneven levels of public research funding, access to scientific talent, and cultural prestige within German science. Especially over recent decades, the institutes have received proportionally more while the universities have received proportionally less from expanding national R\&D investments (Hinze 2016; Hohn 2016). For example, by 2017, even though among European nations Germany spent the most on R\&D (3 percent) relative to its very high GDP, its universities received only 17 percent of these funds, while a significantly larger share went to support research in the well-resourced institutes (OECD.stat 2019). As a result, the institutes' role in scientific discovery enjoys a kind of "favored sponsorship" by the state in terms of resources, and within the general society is reflected in enormous prestige. In contrast, a long simmering "crisis of legitimation" of universities and their role in science has meant that they must do more with less, given the steadily rising student numbers, heavy teaching loads, and increasing competition for research grants (Schimank 1995; Enders et al. 2002; Mohrman et al. 2008; Timmermann 2010; Henke and Pasternack 2017). Accentuating the sense of a crisis is that few of the country's universities achieve top positions in widely publicized international rankings, despite multiple cycles of an "Excellence Initiative" policy designed to select and valorize some leading universities thought then able to compete globally at the highest level.

At the same time, an essential factor in the trajectory of global science has been the rise in the centrality of the research university; in 1900 only a third of the world's scientific papers were authored by university-based scientists, yet over the next 110 years that proportion grew to fully 80 percent of new publications annually (Zhang et al. 2015). Also, recent cross-national investigations find that the research university, particularly so with global mega-science, is robustly productive, even in environments with less than optimal resources (Powell et al. 2017b; Dusdal 2018; Owen-Smith 2018). It is with some irony, then, that the central innovation behind the organizational form of the research university-integrating preparation of future scientists with scientific research-has, at least at the policy level in its country of origin, been differentiated and downgraded to a degree, and that worldwide intensification of this earlier model has not been optimized in Germany's research universities.

The implication of the dual-pillar model is that the institutes lead the way and they form the foundation of the country's science production, while over time universities should have receded in this respect as they focus on teaching and training future scientists. Scientists in universities are, of course, expected to undertake research, but under the dual-pillar policy, disproportionate resources, intellectual prestige, and greatest legitimation for scientific discovery flow towards the institutes. Although this remains a widely held assumption among higher education and research policy makers, it begs the question of what the dual-pillar research policy has meant for science production during the reestablishment of German's scientific 
prominence. Even though the country played a central role in the origins of both forms of doing advanced research, there has never been a systematic, long-historical assessment of their relative impact on Germany's prodigious scientific output (but see Heinze and Kuhlmann 2008 for a two-year assessment). This is now possible to undertake with a unique dataset.

A summary of the historical development of these organizational forms that led to the dual-pillar policy with their now globally atypical differentiated positions sets the context. Then, with national data on STEM+ publications from 1950 to 2010, collected during the international, multidisciplinary project "Science Productivity, Higher Education, Research \& Development, and the Knowledge Society (hereafter SPHERE)," (see Powell et al. 2017a), we address three empirical questions on foundation, mega-science, and efficiency. Firstly, foundationally, to what extent was the primary objective of the dual-pillar research policy achieved: namely, did institutes surpass universities in producing most of the nation's volume of science as university research conditions eroded? Secondly, as also implied by this policy, did institutes adopt regular use of key characteristics of global mega-science production before universities and eclipse them in these practices? Thirdly, is there evidence that institutes are more efficient in science production than universities? Lastly, in light of the results, we consider the logic and future sustainability of the dual-pillar policy and its ensuing sponsorship of institutes as well as university crisis.

\section{Synopsis of the Development of the University and Research Institute}

What is widely acknowledged as the "Humboldtian" model of university-based science stems from four ideals: academic freedom to teach, learn, and inquire; unity of teaching and research for deeper inquiry; broadest possible inquiry including science and humanities; and, primacy of "pure" or basic science striving for universal knowledge. All are underpinned by the elusive, yet frequently extolled, notion that participation in advanced education and its scholarship, and by extension scientific discovery, is essential for nothing short of human cultivation (Bildung). Despite these ideas' centrality as guiding principles, and contrary to popular belief, they never represented a fully articulated formal organizational blueprint for universities in Germany or elsewhere, nor did they mostly spring from Wilhelm von Humboldt the person, nor were they part of one concisely-derived model arising from a single university at a single point (e.g., University of Berlin founded in 1810) (Ash 2006). Nevertheless, over a long developmental period influenced by many thinkers and educationalists at a number of universities primarily in German-speaking regions, there was something substantial and appealing enough in these guiding principles to lead to what is now referred to as the "research university," an organizational form of advanced education and knowledge production assumed to have contributed to the country's pre-eminence in science over the 19th century and facilitating the take-off of the century of science (Rüegg 1999; Lenhardt 2005; Meyer 2017). Slowly evolving out of the Western university from the 14th century, these German forerunners to the contemporary research university were sporadically established from the mid-18th century and then were gradually joined by a steady founding of 
new ones. Over the 18th century, 13 universities based on these ideas to one degree or another were established. By the beginning of the early 19th century, the formation of such universities had become routine.

This early development meant that Germany entered the century of science with functioning research universities that enjoyed enough academic freedom and the integration of education and inquiry to fashion significant capacity to generate new science. On the eve of the take-off of the small science phase in 1900, Germany already had approximately 30 research universities whose faculty members were publishing STEM+ papers in a growing set of journals operating much like the contemporary scientific journal, often published in German. This was the largest set of research universities in a single country, since, for example, the United States, with 25 percent more population, would not have over 30 research universities until the 1920s (Fernandez and Baker 2017). As would be expected, the two world wars and the National Socialist regime along with the 1930s world economic depression shattered Germany's pre-eminence in science. Already by 1931, for example, and through to 1939 more than 3,000 scientists-approximately 40 percent of all scientists in German universities-were forced to leave their positions because of Jewish heritage or oppositional political affiliation (Köhler and Naumann 1994: 652). As shown in Fig. 1, by 1940 the devastation of human and capital resources plus ideological purges and collusion rendered only 24 of its universities-with weakened capability-still publishing basic science in the world's leading journals. Immediately following WWII though, and then on into the big science phase, the university, based on the principles of its forerunners' integration of teaching and research, was reestablished. Over the 1960s the Federal Republic founded research-active universities en masse, so that seven new higher education organizations opened their doors in 1962, and another four did in 1964. The early 1970s saw the most dramatic expansion, with five founded in 1970, 34 in 1971, and seven each in 1973 and 1974. Even though the German Democratic Republic did not generate many STEM+ papers published in Western journals, after reunification in 1990 growth in doctoral degreegranting research universities increased in this region as well. In 2010, Germany had 142 research universities, over one-third as many as in the U.S. with by then four times more population. ${ }^{3}$

The German form of the research university, more or less based on the Humboldtian principles, enjoys a mythical reputation globally, yet its historical reputation is considerably greater than the long-term realization in its country of origin. Ironically the re-establishment of research universities after WWII suffered through underfunding and policies to separate teaching from research. Massive tertiary educational expansion, particularly since the 1960s, established a pattern of chronic underfunding, instead of enrollment-induced equivalent investments that expanded

\footnotetext{
3 East Germany, in line with USSR science policy, adopted state-controlled research academies and did not contribute much to western STEM+ journals. Between 1950 and 1990, the total growth rate in STEM+ paper publication was due mostly to West German-based organizations. The East German system, based on an academy model, provided suboptimal conditions for science production (see Mayntz 1994; Gläser and Meske 1996).
} 
research capacity in other countries' higher education systems (Naumann 1990; Pritchard 2006; Baker and Lenhardt 2008). Increased teaching loads have overshadowed research as rising student enrollments were not accompanied by proportional increases in hiring of professors or senior research staff. Universities seem trapped in a zero-sum dilemma between using set funding allotments for both teaching and research expenditures, and as pressure from the former rose with expansion of enrollments, the latter has suffered (Schimank 1995; Hüther and Krücken 2018). After the onset of the massification of tertiary education in the 1960s, research universities have steadily been taxed with educational tasks such as training approximately two-thirds of the country's total postsecondary enrollment and generating a high $\mathrm{PhD}$ graduate rate, both among the highest rates of all developed national postsecondary systems (OECD 2017). Further de-integration of teaching and research occurred through the establishment of universities of applied sciences (Fachhochschulen), devoted more to teaching in technical fields (not PhD granting) than research. Academically drifting, the Fachhochschulen have gradually increased their participation in research, mostly in collaboration with industry on applied problems (Teichler 2005; Kaiserfeld 2013).

Arguably, the major reason behind this historical paradox is the parallel development and rise in stature of the research institute devoted solely to scientific discovery. In 1911, the Kaiser Wilhelm Society was created as a prominent association of eventually 21 research institutes resourced initially with private funds from industrialists and with considerable legitimation and prestige granted directly from the monarchy. Innovative university-industry research collaborations leading to institutes independent from universities were already occurring, such as Justus Liebig's 1840 research laboratory at the University of Gießen, and later Carl Duisburg's scientific leadership at Bayer AG (Woolf 1984; Rohrbeck 2010). In contrast, the Kaiser Wilhelm Society was founded at the core of Wilhelmine Sammlungspolitik (the politics of national cohesion), essentially at the "institutional apex to concentrate the intellectual achievements of the German nation" (Peacock 2016: 101). With the fall of the German Empire in WWI, these institutes carried on as part of the attempt to rebuild German science and later colluded with the National Socialist regime, including criminally providing technical assistance for the machinery of the Holocaust and other atrocities. After WWII, the society was disbanded and its administrative leaders were tried and imprisoned; then, with clearer legal autonomy from political involvement, this form served as the precursor to the institutes of the Max Planck Society (Max-Planck-Gesellschaft, hereafter MPS) (vom Brocke 1996, 1999; Heim et al. 2009).

Including some research services for industrial applications, the MPS model of an independent research institute was followed in 1949 for applied sciences by institutes of the Fraunhofer Society (Fraunhofer-Gesellschaft zur Förderung der angewandten Wissenschaften); in 1969 for basic and applied research by the Leibniz Association (Wissenschaftsgemeinschaft Gottfried Wilhelm Leibniz); and, in 1995 for large-scale infrastructure by the Helmholtz Association (Helmholtz-Gemeinschaft Deutscher Forschungszentren) (Helmich et al. 2018). With maturing mega-science, Germany significantly founded and funded more institutes with researchers publishing in leading STEM+ journals, rising from 6 in 1970 to 179 in 1990, and to 427 by 2010. And 
unlike universities, since institutes mainly do research, their considerable interlocking federal and state funding allocations are solely dedicated to scientific ends, often oriented to the cutting-edge in specialist fields (see Schimank 1995; Braun 1997).

If the Humboldtian ethos of Bildung culturally permeated the development of the research university, then the related ethos of the "genius" infused the development of the institute. And while each ideal's implementation over the 20th century led to a different path, they stem from a shared source (Watson 2010). Like the holder of a chair-professorship once representing the pinnacle of intellectual preeminence for an entire academic field in the German and European university, the raison d'etre and organization of the institute were, and still are, to maximize the contributions of an identified scientific genius, ideally in the prime of a career, sitting at its head as director and built around him or, rarely, her (Zippel 2017). ${ }^{4}$ This has become known as the "Harnack principle," named after Adolf von Harnack, the first president of the Kaiser Wilhelm Society, and is the embodiment of this genius ethos of the country's research institutes (Vierhaus 1996). More valued even than maintaining a rationalized topical differentiation of science across institutes, the Harnack principle organizes the founding and ending of specific institutes built around selected individual scientists, so if there is no new genius in a particular field (or more likely, the former one retired), the rationale for "his institute" erodes. Softened, the ethos nevertheless lives on; note how a contemporary report from the DAAD (German Academic Exchange Service) describes the institutes of the MPS: "The scientific attractiveness... of the Max Planck Institutes are built up solely around the world's leading researchers, who themselves define their research priorities and are given the best working conditions" (Bode 2015: 38). A director not only has full power over hiring scientific staff and allocating research budget, he or she has full authority over the course of science of the institute (or a department of a larger institute). The institute form was not meant to be a wholly different organization for doing science; in many ways it simply extended one part of the original design of the university: the professor as autonomous generator of new knowledge. The Harnack principle, along with steady flows of significant resources, however, imbues the country's institutes with autonomy and a celebration of excellence well beyond that enjoyed by the research university. From striking, architecturally unique buildings to unabashed self-celebration of its ethos, the institutes capture considerable scientific resources and prestige, thus perpetuating the logic of the dual-pillar research policy (Peacock 2016).

\section{Data and Methods}

\section{Publication Data}

The data analyzed here are STEM+ journal publications with at least one author based at a German university or institute in the decennial years from 1950, by which

\footnotetext{
4 Reflecting well-known gender discrimination in science, the German institute system has been particularly slow to "identify" female geniuses (Zippel 2017).
} 
time the post-WWII institutes began to be a significant part of the formation of the dual-pillar policy, to 2010, and with later starting years for some indicators due to data availability. Despite the increasing role of conference proceedings, reviews, letters, and now direct online sharing of results in some disciplines (e.g., physics sub-fields), the peer-reviewed, STEM+ research article published in an established journal remains the most central record of science to assess sector contributions to national productivity, and is often the foundation for other scientific outcomes, such as patents and applications (Wible 2017).

A total of 176,809 analyzable STEM+ publications is derived from two sources. First, from the decennial years from 1980 to 2010 (and 2005), data originate from Thomson Reuters (now Clarivate Analytics) Web of Science "Science Citation Index Expanded" (SCIE) of about 12,000 leading journals that regularly attract over 95 percent of all citations and represent approximately a quarter of all published research serials in all languages worldwide (Adams 2013). For each publication, the data include date, title, journal title, authors and their affiliations, journal impact factor (JIF), and STEM+ sub-field. To address inevitable inconsistencies across author addresses, such as "Univ of X" versus "University of X," verification and recoding of author affiliations and addresses were completed based on historically consistent codes for all of the country's universities and other organizations with scientists producing STEM+ journal publications. Verification analysis revealed that from 1980 to 2010 the Web of Science coverage of journals was comprehensive, with low rates of missing information on articles and authors' affiliations and addresses; furthermore, these data match supplemental estimates from some of Elsevier's Scopus, the other major database analyzed in bibliometric research (Glänzel 2016). Second, Clarivate Analytics' data prior to 1980 includes a comprehensive database with lists of journals and research article publications; however, country and organization affiliation information are substantially missing. To address this, a sample of publications was drawn and project coders obtained original print copies and extracted author affiliation and city and country information. Using the Clarivate lists for 1950, 1960, and 1970 as the sampling frame, a stratified two-stage sample of journals and then research publications in journals was drawn for each decennial year, with strata of four journal topic categories (Science, Technology, Health, and Other), and of leading journals published in English, German, French, and Russian. Then 5 percent (or 30 titles, whichever was greater) of journals were randomly selected by strata, and from each sampled journal, 30 research publications (or all if less than 35) across the annual issues were randomly selected. Each fully coded publication was then weighted based on the reverse probability of being selected through the two sampling stages to represent the sampling frame of total publications in 1950, 1960, and 1970. These were joined with the 1980 to 2010 data (see Powell et al. 2017b for further details about the sampling method). 


\section{Indicators of University and Institute Sector Productivity}

All indicators are calculated with the standard whole count method, where the university or institute sector total is increased by one for any publication with at least one author affiliation within that sector. Compared to the fractional counting method (fractions of publications counted by sector), appropriate for situations of high crosssector collaboration, when collaborations between sectors are few, the whole count method yields essentially the same totals with minor inflation (Gauffriau et al. 2008; Havemann 2009; Lin et al. 2013). In these data, prior to 2000 university-institute collaboration occurred on less than 3 percent of STEM+ publications, increasing to 12 percent in 2010. A comparison of selected analyses between whole count and fractional count methods in the later decennial years found no differences in main trends and conclusions.

Seven indicators of national science production and productivity, dimensions of "mega-science" style productivity, and efficiency are calculated for various decennial years:

Total STEM+ Publications, 1950-2010.

Total STEM+ Publications by quartiles of journal impact factor, 1980-2010 (1980, 1990 back-coded from scores first calculated in 2000).

Total STEM+ Publications Subfield of journals' topic classified by Clarivate's WoS platform as General Science, Technology, Agriculture, Health, and Other, 1980 and 2010.

High-Impact Journals10 Publications in just the highest decile of journal impact factor, 1980-2010.

High-Impact Journals25 Publications in just the highest quartile of journal impact factor, 1980-2010.

International Collaboration Publications STEM+ publications with authors researching in at least two countries, 1970-2010 (1970 began an escalated trend worldwide).

Efficiency STEM+ for 2005 (the only year personnel data for institutes are available) university sector total STEM+ publications divided by total STEM+ faculty in the university sector (FTE's, as per Kreckel 2008), and the same ratio for scientific personnel (FTE) in all institutes, and another for just the assumed most prestigious MPS (excluding non-STEM+) institutes' personnel (FTE). 


\section{Analytic Approach}

Since the dual-pillar policy has resulted in functional differentiation between sectors with the logical implication that institutes would evidentially eclipse the universities as the foundation of science production (see Powell and Dusdal 2017a, b; Dusdal 2018), this expectation is examined by comparing each sector's total contribution to the estimated combined total of publications (Total STEM+ Publications) over the time period. Then, we compare each sector's contribution to publications of varying quality as indicated by journal impact factor (Total STEM+ Publications Quartiles). Since the two sectors differ in size of total scientific personnel that is addressed in the efficiency analysis below, the first analysis of each sector's aggregate production is in line with the intentions of dual-pillar policy that would be otherwise not revealed by an efficiency ratio. Of course, all analyses are contextualized by sector size to the degree possible. Then, to assess the dual-pillar policy's goal of advancing science production through sector differentiation, each sector's historical timing of incorporation of mega-science production trends is compared on: (1) publications of highest quality (High-Impact Journals10 Publications); (2) subfield diversity of publications (Total STEM+ Publications Subfield); and, (3) publication through international collaborations (International Collaboration Publications) over the period. The analysis of the efficiency question estimates a publication rate per scientific personnel across the two sectors (Efficiency STEM+). Even though neither the umbrella associations of institutes nor the Federal Ministry of Education and Research (Bundesministerium für Bildung und Forschung) maintain annual aggregated data on scientific personnel, we obtained personnel estimates from all institutes and for the most research-intensive MPS institutes for 2005. Lastly, employing the foundation and efficiency approaches for more detail, the one-year efficiency results are then combined with total publications to estimate what hypothetical expansion or reduction in scientists across the two sectors would yield for the nation's future output of STEM+ publications.

\section{Results}

Did Institutes Surpass Universities in Producing Most of Germany's Total STEM+ Publications?

Across the seven decennial years from 1950 to 2010, scientists working in research universities and institutes published an estimated 176,809 STEM+ publications, of which 84 percent were authored by at least one university-based scientist. As shown in Fig. 2, as more institutes were created in the 60 years since 1950 there is some eclipsing of the universities' significant share, which declined from 91 percent of publications in 1950 to 72 percent by 2010. And STEM+ publications with at least one institute-based scientist increased at an annual mean growth rate of 6.9 percent since 1990 compared to 3.7 percent by university scientists, a rate higher than the mean international rate over the same period (Zhang et al. 2015). Nevertheless, the 


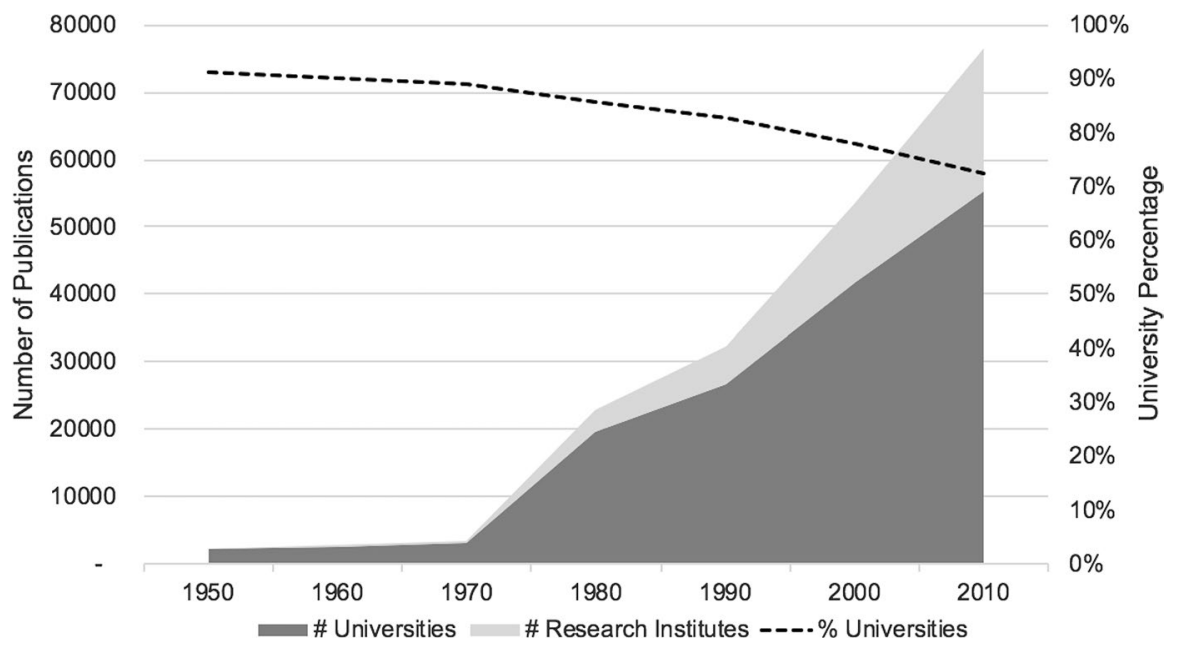

Fig. 2 STEM+ Publications (Whole Counts) from Universities and Research Institutes, and University Percentage, 1950-2010. Source SPHERE project database of SCIE publications (Clarivate Analytics' Web of Science)

scale of production and motivation to produce science by universities continues to be significant, so that in 2010 university-based scientists produced over 55,000 publications compared to 21,000 by institute-based scientists. From 1970, when institutes began to generate meaningful levels of productivity, to 2010 , for every publication written only by institute scientists there were more than three written only by university scientists, which is approximately the same estimated ratio of university to institute scientific personnel in 2005. Also, as noted, collaboration between scientists across the sectors is minimal for most of the period; 12 percent of all papers in 2010

Sector shares relative to journal impact factor indicate each one's impact on the volume of varying quality of publications as shown for the year 2010 in Fig. 3. Proportional to their overall publications share, both sectors contribute to journals at all quality levels. Institutes publish a higher share of their publications in the highest quartile (55 percent) and less in the lowest ( 8 percent) than do universities (43 percent in Q1 versus 16 percent in Q4). Further, institutes have grown their placement in high quartile journals by a rate of 7.5 and universities by 6.3 since 1980 (data not shown in Figure). The much larger university share of science production overall means that, for example, of the approximately 34,000 STEM+ publications in journals with the highest JIF (Q1) in 2010, university scientists produced two for every one by institute scientists; a ratio that only modestly increased towards institutes since 1980. And the same is true at the other end of the quality scale, with university scientists publishing just under three for every one by institute scientists in lowest quartile journals (Q4), but the institutes' growth rate in lower quality journals has been larger than the universities since 1980. Lastly, institutes and universities both published about a quarter of their papers in journals in the second quartile (Q2), while universities publish more in the third quartile (Q3) than do institutes. 


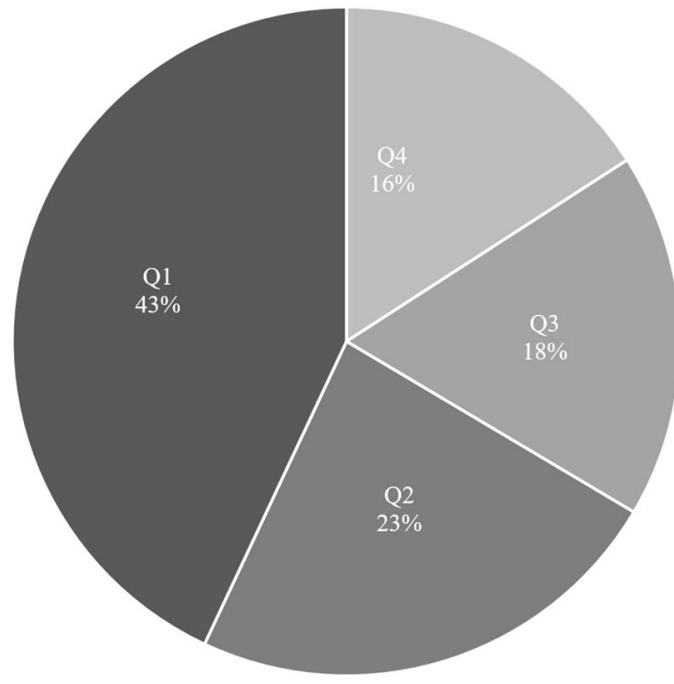

Universities

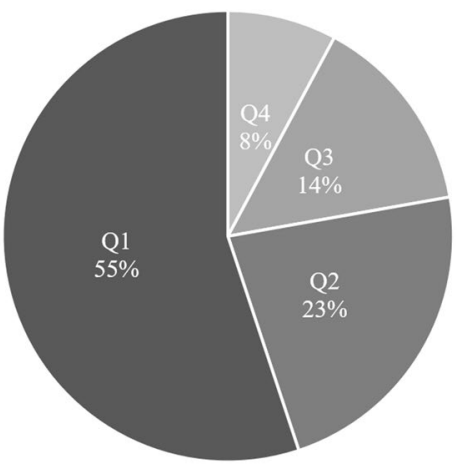

Research Institutes

Fig. 3 Percentage of University and Research Institute Publications (Whole Count) by Quartiles of Journal Impact Factor, 2010 Proportional to Sector Share. Source SPHERE project database of SCIE publications (Clarivate Analytics' Web of Science)

Did Institutes Adopt Key Characteristics of Global Mega-Science Production Before Universities and Eclipse them in these Practices?

One of three central features of global mega-science production is sustained competition to achieve high-quality scientific discovery and hence to publish in journals with the highest JIF. Focusing on just the highest decile, Fig. 4 shows that more or less consistently since 1980, university scientists have produced just over two-thirds of these papers. In 1980, universities published over 1,100 highest quality STEM+ publications, while institutes produced just over 500. And from 2000 on, institutes and universities grew these kinds of rarer publications at about the same rate of 1.8 percent and 1.5 percent, respectively.

A second feature is diversity in science production. As shown in Fig. 5, institutes' publications have been primarily published in the general area of science journals, while universities have considerably greater diversity in topics since the 1980s. Partially attributable to university-affiliated hospitals and medical centers, by 2010 university-based scientists were publishing over four out of ten publications in journals with topics other than general science, including almost a third in health-medical journals, just under 10 percent in technology journals, and 4 percent in agricultural journals. In the same period, institute-based scientists published about three-quarters of their publications in general science, and about 10 percent each in health and technology journals.

The final feature is engagement in international collaborations. As shown in Fig. 6, by 1970 university-based scientists were already producing nearly all of 


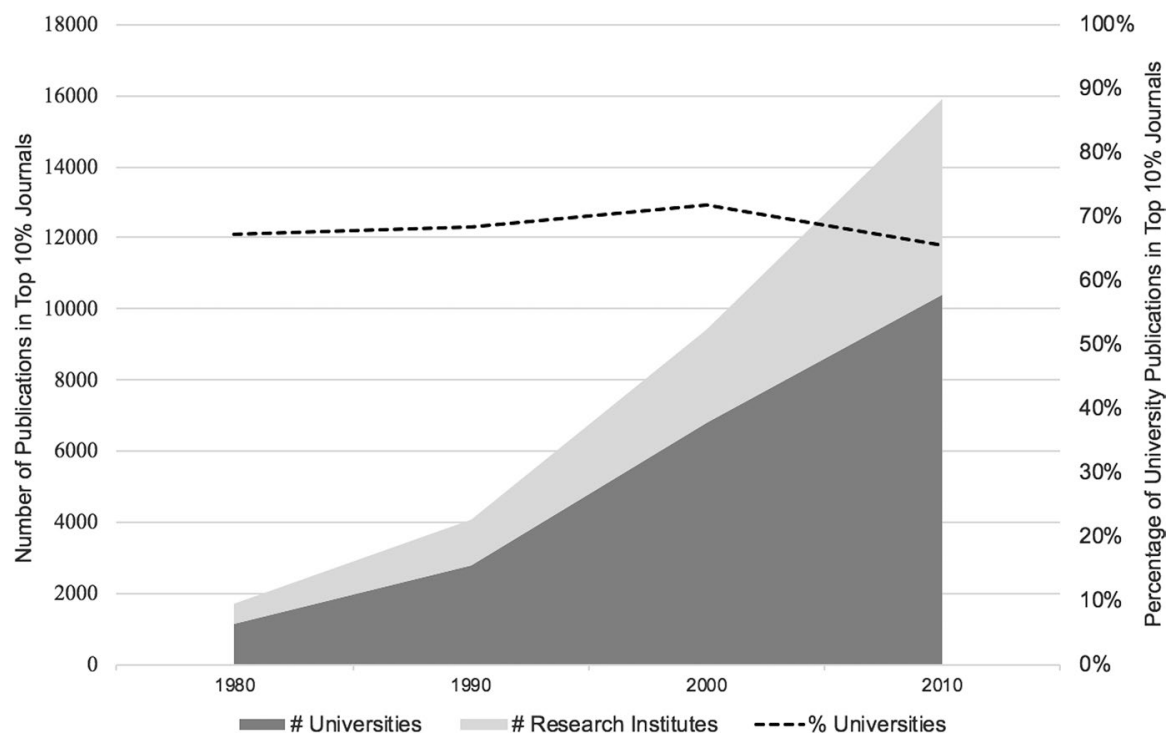

Fig. 4 Totals and Percentage of University and Research Institute Publications (Whole Count) in Highest Decile of Journal Impact Factor, 1980-2010. Source SPHERE project database of SCIE publications (Clarivate Analytics' Web of Science)

the nation's international collaborations and by 1980 were doing so at double the world's average rate of 2 percent. Ten years later, international collaborative publications by institute scientists had grown to about one-third, and this ratio remained nearly consistent for the rest of the period. Also, both sectors grew international collaborations steeply from 1990, with institutes growing slightly faster ( 8 percent) than universities (7 percent) from 2000 to 2010, a mega-trend that continues to advance rapidly (see e.g. Powell 2018; Dusdal et al. 2019).

\section{Are Institutes More Efficient than Universities in Science Production?}

For 2005, an estimate of scientific personnel size indicates that there were approximately three university scientists for every institute scientist; and, the ratio of the total number of publications per scientist at all institutes is 0.57 , and 0.77 at just the Max Planck institutes, while for universities the ratio is 0.51 (see also Bornmann et al. 2012; Helmich et al. 2018: 20). ${ }^{5}$ Therefore, assuming the higher MPS rate of production, for institutes to produce the approximately 32,000 additional publications it would have taken to equal total university production in 2005 , institutes would have required 63 percent more scientific personnel.

\footnotetext{
5 For all papers, we note that because the obtained personnel counts of both pillars mix scientists at all levels of career development, from post-doctoral fellows and technicians with doctorates to senior investigators with established labs, there is likely a wide dispersion around these mean ratios.
} 


\section{0}
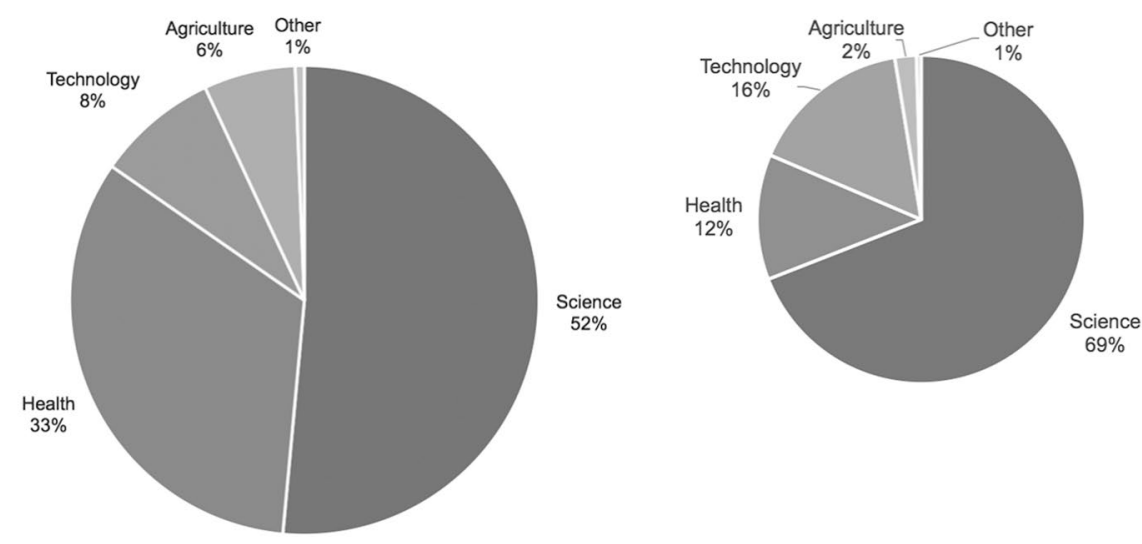

\section{0}

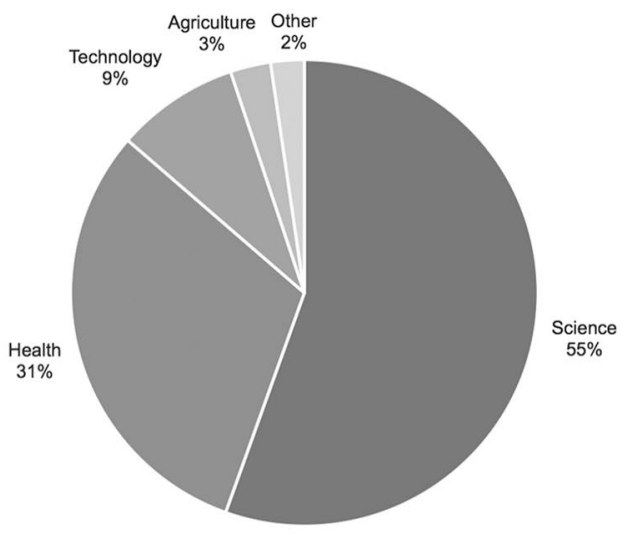

Universities

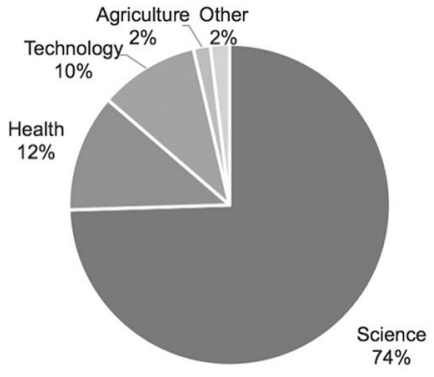

Research Institutes

Fig. 5 Proportion of University and Research Institute Publications (Whole Count) by Journal Topics of Science, Technology, Agriculture, Health and Other. 1980 and 2010 Proportional to Sector Share. Source SPHERE project database of SCIE publications (Clarivate Analytics' Web of Science)

\section{Discussion of Results}

The results support two observations. First, as the dual-pillar policy approach would have it, the institute sector has been very successful in contributing to the nation's scientific output reflected in STEM+ publications. It has grown logarithmically to publish just over 30 percent of the total, including a third of higher quality publications. Also, institute science took on the qualities of mega-science production with about a third of the nation's publications in the top decile of journals, some increased diversity across scientific sub-topics, and growing international collaborations, at least since 2000. Lastly, there is some evidence that institutes are efficient. 


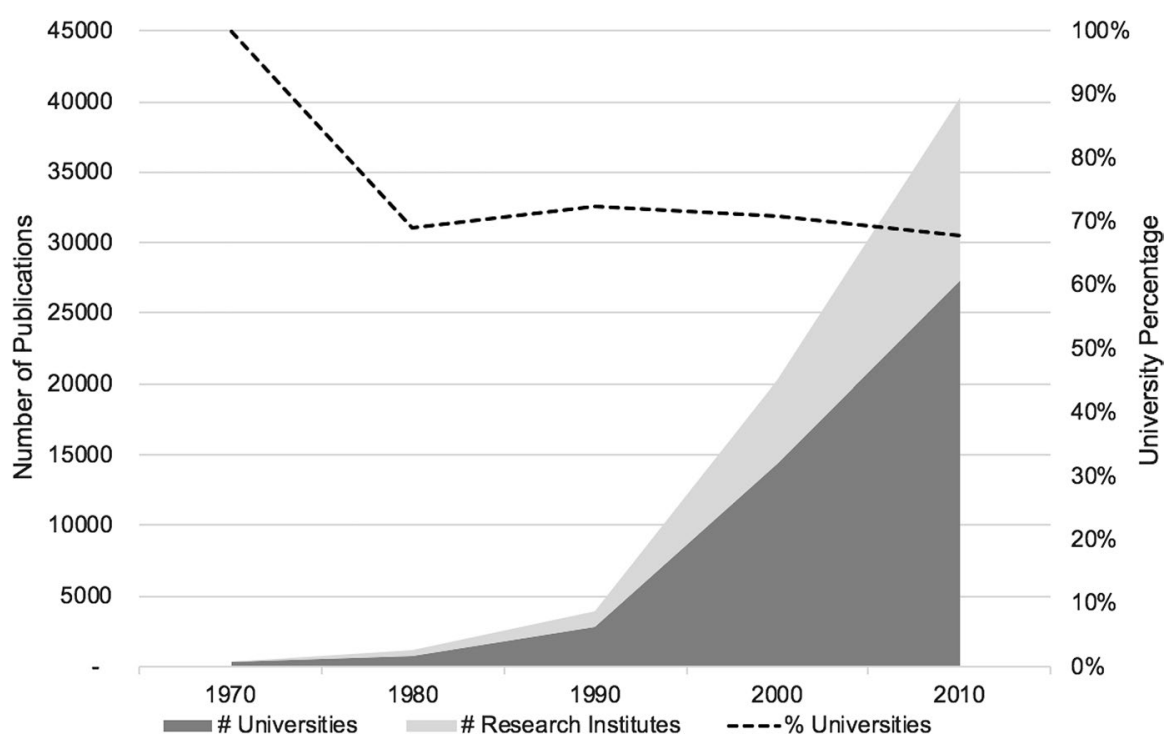

Fig. 6 International Collaboratively-authored Publications (Whole Count) from Universities and Research Institutes, and University Percentage of Total International Collaborations, 1970-2010. Source SPHERE project database of SCIE publications (Clarivate Analytics' Web of Science)

Given this sector's superior financial, recruitment, and working conditions, this performance may well be expected. But does this success mean that a full dual-pillar structure is emergent and institutes will soon mostly surpass universities in research productivity? Or that the institutes produce the vast majority of publications in highest quality journals? Or that universities have been less involved in mega-science style production and, also given their substantial other functions like education, woefully inefficient?

Since the answer is thrice no, the second observation is that universities have, despite the rapid increase in higher education enrollments, yet without proportional increases in infrastructural funding, successfully maintained their key research role. They are the major base for the nation's science production, even with the development of a significant institute sector (see a similar conclusion based on the two-year comparison by Heinze and Kuhlmann 2008). It is true that since 1990 the institutes' growth rate in total publications is higher, but the universities' rate of logarithmic growth of a larger base is higher than the mean international rate over the same period, which, as noted, is mostly based on universities worldwide. Institutes have proportionally published more in the highest quartile of journals and less in lower impact journals, but universities are responsible for two-thirds of all top decile journal publications, growing these rarer publications at about the same rate as institutes. While institutes are involved in mega-science trends, scientists at universities were likely doing so with greater participation earlier. This is obviously the case for diversification of sub-topics and international collaborations, and perhaps less so for top decile journal publications with universities and institutes already at a stable 2 to 1 ratio by 1980 . Institute scientists doing full-time research are likely more efficient 
than university faculty who also have significant non-research responsibilities, but not by much, except when compared to the subset of researchers at highly resourced Max Planck institutes. Even then, at an additional quarter of a publication per scientist, the difference is not that large. Indeed, for the institute sector to totally replace the university sector's output, we estimate it would require more than doubling an already extremely large funding stream.

Instead of an image of dual pillars, the more accurate image of the two sectors' relative historical performance is that each produced approximately similar publication records relative to their size. The creation of institutes has added research capacity and this sector published more of the nation's higher quality publications than its size would predict, at least by 2005 for which there is data on their personnel. At the same time though, evidence that production from institutes is qualitatively different in proportional contribution or mega-science style from that of the larger university sector is not overwhelming. Of course, as with all assessments of scientific productivity, the choice of indicators and data comes with limitations (Gingras 2016). Obviously, the volume of peer-reviewed journal research publications, plus journal impact, subject diversity, and international collaboration does not entail a full evaluation of scientific production and productivity, and each has known deficiencies as an indicator (Lin, Huang, and Chen 2013). Nevertheless, these data do provide the first broad historical comparison from which to assess the impact on the nation's science output; the used indicators are reasonable and so the results likely do reflect main trends.

\section{Conclusions}

As successful as the institutes have been, universities have, nevertheless, formed the bedrock upon which Germany reestablished so much of its scientific prominence among the highly competitive European and global science systems since the nadir of 1945. By the beginning of maturing mega-science in the 1980s-well before the much-touted emergence of China and other leading science producers in East Asia-it was European-based science that reemerged to rival U.S. domination. As the results indicate, German universities were key to this revival. Even in a country with arguably the world's best organized, funded, and prestigious system of independent research institutes - one in which universities were viewed and treated principally by many as primarily providers of higher education and professional training - research universities continued to provide the majority of publications. They have played the major role in securing Germany's pathway to the forefront of megascience trends.

In terms of the success of research institutes, the dual-pillar policy has certainly worked, yet it has, thus far, come with the cost of what may be considered an underappreciation of what universities have, and still do, accomplish in terms of research and intergenerational transmission of knowledge as foundational for the entire science system. The assumptions driving this policy led to a kind of myth of separate functionality that belies the actual record of the nation's renewed rise to prominence in science during the latter quarter of the 20th century. Like in other scientifically 
productive nations, Germany's research universities do undertake most of the training of scientists. As in most other nations, these universities contribute the largest share of STEM+ publications and are heavily engaged in mega-science style production. Except with the addition of a successful institutes sector, the empirical trends in Germany are not very different from global ones in which the research university has intensified its centrality in science production (Zhang et al. 2015).

The key reason for this is the robustness of the organizational form of the research university, based on the very model that Germany was so instrumental in establishing. As noted above, the fact that, worldwide, the research university is the core source of mega-science STEM+ publications is in part attributable to the early German and Central European innovations of integrating knowledge production and advanced scientific training, which was then intensified in the U.S. (Baker 2014; Brint and Carr 2017; Owen-Smith 2018), and is now globally emulated. Counter to earlier predictions of the decline of universities in new science production, this model has proved very durable and is at the core of the now approaching two million annual journal publications from all world regions (Powell et al. 2017a, b). Research universities are the world's core organizational form in providing the platform for exchange among members of all other organizational forms: they are autonomous; benefit from intergenerational exchange and the insights, energy, and ambitions of young scholars; connect the broadest possible array of disciplines; and are deeply embedded in the global networks that facilitate the essential collaborations leading to innovation in today's scientific communities (Dusdal et al. 2019).

As a country with substantial research investments in another organizational form, the contemporary German case enhances this argument by adding several crucial pieces of evidence about the centrality of the university in the formation and rise of global mega-science (Baker and Powell forthcoming). One is the relative success of universities, even within an intentionally bifurcated research policy. Perhaps the largest unintended consequence of this policy is that the current German university's research environment is neither structured nor funded along the lines of full implementation of the emerging global model. The dual-pillar myth undergirding contemporary research policy devalues what universities can do for scientific advance. Nevertheless, the analysis indicates the efficacy of the research university model even when sub-optimally supported, as Germany's substantial scientific contributions fundamentally rest upon its universities (Dusdal 2018). Universities, for example, may be better situated than institutes to leverage graduate students and post-docs and even undergraduates for research purposes; to create motivation and some efficiency in environments requiring both teaching and research; and, to better absorb mediocrity or to create pressures for excellence, especially as the Excellence Initiative, with relatively meagre funds, emphasizes competition among relatively equal universities.

Similarly, while the German case is perhaps extreme in its rhetoric and funding implications, its logic nevertheless continues to appeal. Indeed, recent research policy in France also addresses the gaps between universities and research institutesunderstood as problematic-especially the relationship between CNRS laboratories and universities, still viewed primarily as teaching-oriented, in both funding levels and prestige (Robin and Schubert 2013; Musselin 2017; Powell and Dusdal 2017a, 
b). Even in the U.S., where the research university dominates science production, through the small science and big science phases, a reoccurring countertheme lobbied for focused funding mostly to the "best and brightest" scientists in dedicated environments, often with reference to early 20th century European nations (Brint and Carr 2017; Fernandez and Baker 2017).

Other evidence includes the interaction of the dual-pillar policy and the comparatively late mass university enrollments. A less-appreciated causal element in research universities' success in the U.S. and then elsewhere is that it coincided with growing proportions of young adults entering post-secondary education. As demand for access to universities grew and intensified, nations responded in various ways (public, private, and combinations) by expanding universities, resulting in growth (and motivation) of science-producing faculty and related graduate training. This is one chief reason why the U.S. had over 200 STEM+ productive universities by 1980, while Germany's university expansion occurred later and less rapidly than in many other high-income nations (Hüther and Krücken 2018: 48; Baker and Powell forthcoming). And even in light of excellence initiatives among universities, the dual-pillar policy may have restrained the substantial scientific dividend from postsecondary expansion that occurred in other countries such as South Korea, China, and Taiwan.

Lastly, as is too often taken-for-granted, in German educational and scientific fields, dual structures are culturally maintained, leading to stratification and institutional impermeability - whether differentiated school types in secondary education, the durable "schism" between vocational training and higher education (Powell and Solga 2011; Baethge and Wolter 2015), or the dual-pillars policy examined here. And such a culture can limit both sides of a dual structure. For example, even though institutes themselves have recently "academically drifted" towards some integration of doctoral education, it may not go in both directions since recent efforts to support cross-sector collaboration have had only weak success (i.e., 12 percent of 2010 publications), in overcoming challenges of limited funding, incompatible organizational missions and working cultures, and differential status and access to facilities (Heinze and Kuhlmann 2008; Dusdal 2018). Again, the dual-pillar approach perpetuates a separation that ultimately may not be the best for the nation's science productivity in both sectors into the future.

The historical arc of these results also has policy implications. Investment in institutes yields significant science production in both quantity and quality. Yet, if the dual-pillar model from which it springs leads to research policy providing lower university funding levels and lessens effective research conditions in universities, it may not be optimal for a nation's total scientific output. By reducing the quality and autonomy of scientists as competition for university-based postdoctoral and professorial positions continues to rise, it may also reduce the necessary organizational capacity to produce the next generation of scientists. While a more Machiavellian attitude towards the results from universities might be that they "can achieve plenty with less," this, in our view, is ultimately shortsighted. Research policy must attend to dilemmas of resource distribution, emphasize university and institute strengths, and delve deeper into increasingly important questions of collaboration across organizational, disciplinary, and cultural boundaries. What costs in terms 
of scientific production did the weakening of the innovative integration of research and teaching at the heart of the research university have? What consequences would improved funding and working conditions for all of Germany's universities, instead of solely those that succeed in the Excellence Initiative, have?

Based on our results, the dual-pillar research policy of stratification of research institutes and research universities and limited funding of university infrastructure and research seems questionable in the era of university-dominated global mega-science. Certainly, in Germany and elsewhere, research institutes contribute to a differentiated and highly productive science system, yet perhaps with unintended negative consequences, such as valid criticisms about precarious career chances of the middle tier of young scientists on temporary contracts (Peacock 2016). The results indicate that in reality there is no complete differentiation in the functioning of Germany's science system. Research universities train young scholars and produce most of the STEM+ research, as reflected in the peer-reviewed articles appearing in leading journals. In an age of exponentially growing collaboration, the question of utility of the dual-pillar model and its policy implications should be explicitly addressed. Perhaps Germany's already major science production could be further increased were its universities given resources (human, material and prestige) to fully implement the globally productive research university model that its own early universities inspired around the world.

Acknowledgments For valuable feedback on earlier versions of this paper, we thank our SPHERE team members and this journal's reviewers.

Funding This work was supported by the Qatar National Research Fund, a member of Qatar Foundation [NPRP Grant No. 5-1021-5-159]. The findings herein are solely the responsibility of the authors.

Open Access This article is licensed under a Creative Commons Attribution 4.0 International License, which permits use, sharing, adaptation, distribution and reproduction in any medium or format, as long as you give appropriate credit to the original author(s) and the source, provide a link to the Creative Commons licence, and indicate if changes were made. The images or other third party material in this article are included in the article's Creative Commons licence, unless indicated otherwise in a credit line to the material. If material is not included in the article's Creative Commons licence and your intended use is not permitted by statutory regulation or exceeds the permitted use, you will need to obtain permission directly from the copyright holder. To view a copy of this licence, visit http://creativecommons.org/licen ses/by/4.0/.

\section{References}

Adams, Jonathan. 2013. The Fourth Age of Research. Nature 497(4751): 557-560.

Ash, Mitchell G. 2006. Bachelor of What, Master of Whom? The Humboldt Myth and Historical Transformations of Higher Education in German-Speaking Europe and the US. European Journal of Education 41(2): 245-267.

Baethge, Martin, and Andrä Wolter. 2015. The German Skill Formation Model in Transition: From Dual System of VET to Higher Education? Journal of Labour Market Research 48(2): 97-112.

Baker, David P. 2014. The Schooled Society: The Educational Transformation of Global Culture. Stanford: Stanford University Press.

Baker, David P., and Gero Lenhardt. 2008. The Institutional Crisis of the German Research University. Higher Education Policy 21: 49-64. 
Baker, David P., and Justin J.W. Powell. forthcoming. Global Mega-Science: Universities Scientize the World. Stanford, CA: Stanford University Press.

Bode, Christian. 2015. Kommentierte Grafiken zum deutschen Hochschul- und Forschungssystem. Bonn: DAAD.

Bornmann, Lutz, Benjamin F. Bowman, Johann Bauer, Werner Marx, Hermann Schier, and Margit Palzenberger. 2012. Standards für die Anwendung der Bibliometrie bei der Evaluation von Forschungsinstituten im Bereich der Naturwissenschaften. Zeitschrift für Evaluation 11(2): 233-260.

Braun, Dietmar. 1997. Die politische Steuerung der Wissenschaft. Frankfurt/Main: Campus.

Brint, Steven, and Cynthia E. Carr. 2017. The Scientific Research Output of U.S. Research Universities, 1980-2010: Continuing Dispersion, Increasing Concentration, or Stable Inequality? Minerva 55(4): 435-457.

de Solla Price, Derek J. 1963. Little Science, Big Science. New Haven, CT: Yale University Press.

de Solla Price, Derek J. 1986. Little Science, Big Science and Beyond. New York: Columbia University Press.

Dusdal, Jennifer. 2018. Welche Organisationsformen produzieren Wissenschaft? Zum Verhältnis von Hochschule und Wissenschaft in Deutschland. Frankfurt/Main: Campus.

Dusdal, Jennifer, Achim Oberg, and Justin J.W. Powell. 2019. Das Verhältnis zwischen Hochschule und Wissenschaft in Deutschland: Expansion-Produktion-Kooperation. In Komplexe Dynamiken globaler und lokaler Entwicklungen-39. Kongress der Deutschen Gesellschaft für Soziologie, ed. Deutsche Gesellschaft für Soziologie. https://publikationen.soziologie.de/index.php/kongressba nd_2018/article/view/1109. Accessed 20 November 2019.

Enders, Jürgen, Barbara Kehm, and Uwe Schimank. 2002. Structures and Problems of Research in German Higher Education. In Trends in American and German Higher Education, ed. Robert McC Adams, 85-119. Cambridge, MA: American Academy of Arts and Sciences.

Felt, Ulrike, Helga Nowotny, and Klaus Taschwer. 1995. Wissenschaftsforschung. Frankfurt/Main: Campus.

Fernandez, Frank, and David P. Baker. 2017. Science Production in the United States: An Unexpected Synergy between Mass Higher Education and the Super Research University. In The Century of Science, eds. Justin J.W. Powell, David P. Baker, and Frank Fernandez, 81-111. Bingley, UK: Emerald Publishing.

Gauffriau, Marianne, Peder Olesen Larsen, Isabelle Maye, Anne Roulin-Perriard, and Markus von Ins. 2008. Comparison of Results of Publication Counting Using Different Methods. Scientometrics 77(1): 147-176.

Geiger, Roger L. 2004 [1993]. Research and Relevant Knowledge: American Research Universities since World War II. New Brunswick, NJ: Transaction Publishers.

Gingras, Yves. 2016. Bibliometrics and Research Evaluation: Uses and Abuses. Cambridge, MA: MIT Press.

Glänzel, Wolfgang. 2016. Bibliometrics. A Concise Introduction. https://www.ecoom.be/en/research/ bibliometrics. Accessed 29 August 2018.

Gläser, Jochen, and Werner Meske. 1996. Anwendungsorientierung von Grundlagenforschung? Erfahrungen der Akademie der Wissenschaften der DDR. Frankfurt/Main: Campus.

Havemann, Frank. 2009. Einführung in die Bibliometrie. Berlin: Gesellschaft für Wissenschaftsforschung. Heim, Susanne, Carola Sachse, and Mark Walker (eds.). 2009. The Kaiser Wilhelm Society under National Socialism. Cambridge, UK: Cambridge University Press.

Heinze, Thomas, and Stefan Kuhlmann. 2008. Across Institutional Boundaries? Research Collaboration in German Public Sector Nanoscience. Research Policy 37(5): 888-899.

Helmich, Patricia, Sonia Gruber, and Rainer Frietsch. 2018. Performance and Structures of the German Science System 2017. Studien zum deutschen Innovationssystem Nr. 5-2018. Berlin: Fraunhofer Institute for Systems and Innovation Research ISI; Expertenkommission Forschung und Innovation (EFI).

Henke, Justus, and Peer Pasternack. 2017. Hochschulsystemfinanzierung. Wegweiser durch die Mittelströme. HoF-Handreichungen 9. Wittenberg: Institut für Hochschulforschung (HoF).

Hinze, Sybille. 2016. Forschungsförderung und ihre Finanzierung. In Handbuch Wissenschaftspolitik, 2nd ed, eds. Dagmar Simon, Andreas Knie, Stefan Hornbostel, and Karin Zimmerman, 413-428. Wiesbaden: VS Verlag für Sozialwissenschaften.

Hohn, Hans-Willy. 2016. Governance-Strukturen und institutioneller Wandel des außeruniversitären Forschungssystems Deutschlands. In Handbuch Wissenschaftspolitik, 2nd ed, eds. Dagmar Simon, 
Andreas Knie, Stefan Hornbostel, and Karin Zimmerman, 549-572. Wiesbaden: VS Verlag für Sozialwissenschaften.

Hüther, Otto, and Georg Krücken. 2018. Higher Education in Germany-Recent Developments in an International Perspective. Cham: Springer.

Kaiserfeld, Thomas. 2013. Why New Hybrid Organizations are Formed: Historical Perspectives on Epistemic and Academic Drift. Minerva 51(2): 171-194.

Köhler, Helmut, and Jens Naumann. 1994. Das Hochschulwesen. In Das Bildungswesen in der Bundesrepublik Deutschland, eds. Arbeitsgruppe Bildungsbericht am MPI für Bildungsforschung, 634683. Reinbek: Rowohlt.

Kreckel, Reinhard (ed.). 2008. Zwischen Promotion und Professur. Leipzig: Akademische Verlagsanstalt.

Lenhardt, Gero. 2005. Hochschulen in Deutschland und den USA. Wiesbaden: VS Verlag für Sozialwissenschaften.

Lin, Chi-Shiou, Mu-Hsuan Huang, and Dar-Zen Chen. 2013. The Influences of Counting Methods on University Rankings Based on Paper Count and Citation Count. Journal of Informetrics 7(3): 611-621.

Mayntz, Renate. 1994. Deutsche Forschung im Einigungsprozeß. Frankfurt/Main: Campus.

Meyer, Heinz-Dieter. 2017. The Design of the University: German, American, and 'World Class'. Abingdon: Routledge.

Mohrman, Kathryn, Wanhua Ma, and David P. Baker. 2008. The Research University in Transition: The Emerging Global Model. Higher Education Policy 21(1): 5-27.

Musselin, Christine. 2017. La Grande Course des Universités. Paris: Presses de Sciences Po.

Naumann, Jens. 1990. Das Hochschulwesen. In Das Bildungswesen in der Bundesrepublik Deutschland, eds. Arbeitsgruppe Bildungsbericht am MPI für Bildungsforschung, 370-401. Reinbek: Rowohlt.

OECD. 2017. Education at a Glance 2017. Paris: OECD.

OECD.stat. 2019. Main Science and Technology Indicators. https://stats.oecd.org/Index.aspx?DataS etCode=MSTI_PUB. Accessed 29 August 2018.

Oleksiyenko, Anatoly. 2014. On the Shoulders of Giants? Global Science, Resources, Asymmetries, and Repositioning of Research Universities in China and Russia. Comparative Education Review 58(3): 482-508.

Owen-Smith, Jason. 2018. Research Universities and the Public Good: Discovery for an Uncertain Future. Stanford: Stanford University Press.

Peacock, Vita. 2016. Academic Precarity as Hierarchical Dependence in the Max Planck Society. HAU: Journal of Ethnographic Theory 6(1): 95-119.

Powell, Justin J.W. 2018. Higher Education and the Exponential Rise of Science: Competition and Collaboration. In Emerging Trends in the Social and Behavioral Sciences, eds. Robert Scott and Marlis Buchmann, 1-17. https://onlinelibrary.wiley.com/doi/book/10.1002/9781118900772. Accessed 20 November 2019.

Powell, Justin J.W., and Heike Solga. 2011. Why are Higher Education Participation Rates in Germany so Low? Institutional Barriers to Higher Education Expansion. Journal of Education and Work 24(1): 49-68.

Powell, Justin J.W., and Jennifer Dusdal. 2017a. Science Production in Germany, France, Belgium, and Luxembourg: Comparing the Contributions of Research Universities and Institutes to Science, Technology, Engineering, Mathematics, and Health. Minerva 55(4): 413-434.

Powell, Justin J.W., and Jennifer Dusdal. 2017b. The European Center of Science Productivity: Research Universities and Institutes in France, Germany, and the United Kingdom. In The Century of Science, eds. Justin J.W. Powell, David P. Baker, and Frank Fernandez, 55-84. Bingley, UK: Emerald Publishing.

Powell, Justin J.W., David P. Baker, and Frank Fernandez (eds.). 2017a. The Century of Science: The Global Triumph of the Research University, International Perspectives on Education and Society Series, 33. Bingley, UK: Emerald Publishing.

Powell, Justin J.W., Frank Fernandez, John T. Crist, Jennifer Dusdal, Liang Zhang, and David P. Baker. 2017b. Introduction: The Worldwide Triumph of the Research University and Globalizing Science. In The Century of Science, eds. Justin J.W. Powell, David P. Baker, and Frank Fernandez, 1-36. Bingley, UK: Emerald Publishing.

Pritchard, Rosalind M.O. 2006. Trends in the Restructuring of German Universities. Comparative Education Review 50(1): 90-112.

Robin, Stéphane, and Torben Schubert. 2013. Cooperation with Public Research Institutions and Success in Innovation: Evidence from France and Germany. Research Policy 42(1): 149-166. 
Rohrbeck, René. 2010. F+E-Politik von Unternehmen. In Handbuch Wissenschaftspolitik, eds. Dagmar Simon, Andreas Knie, and Stefan Hornbostel, 427-440. Wiesbaden: VS Verlag für Sozialwissenschaften.

Rüegg, Walter. 1999. Ortsbestimmung. Die Königlich Preußische Akademie der Wissenschaften und der Aufstieg der Universitäten in den ersten zwei Dritteln des 19 Jahrhunderts. In Die Königlich Preußische Akademie der Wissenschaften zu Berlin im Kaiserreich, ed. Jürgen Kocka, 23-40. Berlin: Akademie Verlag.

Schimank, Uwe. 1995. Hochschulforschung im Schatten der Lehre. Frankfurt/Main: Campus.

Teichler, Ulrich. 2005. Hochschulstrukturen im Umbruch. Frankfurt/Main: Campus.

Timmermann, Dieter. 2010. Alternativen der Hochschulfinanzierung. Arbeitspapier 121 der Hans-Böckler-Stiftung. https://www.boeckler.de/pdf/p_arbp_211.pdf. Accessed 29 August 2018.

Vierhaus, Rudolf. 1996. Bemerkungen zum sogenannten Harnack-Prinzip Mythos und Realität. In Die Kaiser-Wilhelm/Max Planck Gesellschaft und ihre Institute, eds. Bernhard vom Brocke and Hubert Laitko, 129-138. Berlin: de Gruyter.

vom Brocke, Bernhard. 1996. Institute und Forschungsstellen der KWG/MPG 1911-1995. In Die KaiserWilhelm/Max Planck Gesellschaft und ihre Institute, eds. Bernhard vom Brocke and Hubert Laitko, 633-640. Berlin: de Gruyter.

vom Brocke, Bernhard. 1999. Verschenkte Optionen. Die Herausforderung der Preußischen Akademie durch neue Organisationsformen der Forschung um 1900. In Königlich Preußische Akademie der Wissenschaften zu Berlin im Kaiserreich, eds. Jürgen Kocka, 119-147. Berlin: Akademie Verlag.

Watson, Peter. 2010. The German Genius. New York: HarperCollins.

Wible, Brad. 2017. Patents from Papers both Basic and Applied. Science 356(6333): 37-38.

Woolf, Harry. 1984. Basic Research and Industrial Enterprise. Minerva 22(2): 183-195.

Zhang, Liang, Justin J.W. Powell, and David P. Baker. 2015. Exponential Growth and the Shifting Global Center of Gravity of Science Production, 1900-2011. Change The Magazine of Higher Learning 47(4): 46-49.

Zippel, Kathrin. 2017. Women in Global Science. Stanford, CA: Stanford University Press.

Publisher's Note Springer Nature remains neutral with regard to jurisdictional claims in published maps and institutional affiliations. 